\title{
Crop residue management in arable cropping systems under temperate climate. Part 1: Soil biological and chemical (phosphorus and nitrogen) properties. A review
}

\author{
Aboulkacem Lemtiri ${ }^{(1,2)^{*}}$, Florine Degrune ${ }^{(1,3) *}$, Sophie Barbieux ${ }^{(1,2)}$, Marie-Pierre Hiel ${ }^{(1,4)}$, \\ Marie Chélin ${ }^{(1,2)}$, Nargish Parvin ${ }^{(1,2)}$, Micheline Vandenbol ${ }^{(3)}$, Frédéric Francis ${ }^{(5)}$, \\ Gilles Colinet ${ }^{(2)}$ \\ (1) University of Liège - Gembloux Agro-Bio Tech. TERRA. AgricultureIsLife. Passage des Déportés, 2. BE-5030 Gembloux \\ (Belgique).E-mail: alemtiri@doct.ulg.ac.be \\ (2) University of Liège - Gembloux Agro-Bio Tech. Biosystems Engineering. Soil-Water-Plant Exchanges. Passage des \\ Déportés, 2. BE-5030 Gembloux (Belgique). \\ (3) University of Liège - Gembloux Agro-Bio Tech. Agrobiochem. Microbiology and Genomics Unit. Avenue Maréchal Juin, \\ 6. BE-5030 Gembloux (Belgique). \\ (4) University of Liège - Gembloux Agro-Bio Tech. Agrobiochem. Crop Sciences. Passage des Déportés, 2. BE-5030 \\ Gembloux (Belgium). \\ ${ }^{(5)}$ University of Liège - Gembloux Agro-Bio Tech. Agrobiochem. Functional and Evolutionary Entomology. Passage des \\ Déportés, 2. BE-5030 Gembloux (Belgium). \\ * These authors contributed equally to this paper.
}

Received on April 1, 2015; accepted on March 7, 2016.

Introduction. Interacting soil organisms support biological processes that participate in soil functions, organic matter decomposition, and nutrient cycling. Earthworms and microorganisms play a range of beneficial roles in agricultural systems, including increased organic matter mineralization, nutrient cycling, and soil structure stabilization.

Literature. The following aspects of crop residue management effects are examined in this paper: (i) earthworm composition and structure; (ii) soil microbial communities; and (iii) phosphorus $(\mathrm{P})$ and nitrogen $(\mathrm{N})$ element availability and distribution in the soil profile. Conventional tillage (ploughing) is often reported to generate decreased soil organism abundance and diversity, primarily earthworms and microorganisms, as well as a uniform distribution of the nutrients $\mathrm{P}$ and $\mathrm{N}$ within the ploughed soil horizon. Soil residue incorporation of mineral particles can maintain $\mathrm{P}$ and $\mathrm{N}$ levels, however returning soil also increases aeration and the activation of microbial activity. Hence, comparisons of tillage effects on soil biological functioning and nutrient cycling remain unclear.

Conclusions. This review highlights the challenges in establishing definitive evidence regarding the effects of crop residue management on soil organisms and nutrient dynamics. The studies examined reported variability in soil and climate, and the complexity of soil processes contributed to the absence of clear findings. Further research is required under temperate climate conditions.

Keywords. Crop residues, tillage, earthworms, microorganisms, phosphorus, nitrogen, temperate climate.

Gestion des résidus de cultures dans les systèmes de grandes cultures sous climat tempéré. Partie 1 : Propriétés biologique et chimique (phosphore et azote) du sol (synthèse bibliographique)

Introduction. Les processus biologiques qui favorisent les fonctions du sol, la transformation du carbone, la décomposition de la matière organique et le cycle des éléments nutritifs sont assurés par les différents organismes du sol. En agriculture, les vers de terre et les micro-organismes fournissent un éventail de rôles bénéfiques, notamment la minéralisation accrue de la matière organique et la stabilisation de la structure du sol.

Littérature. Cet article met l'accent sur l'effet de la gestion des résidus de récolte sur (i) la composition et la structure de la communauté lombricienne, (ii) les communautés microbiennes du sol, (iii) la disponibilité et la distribution spatiale des teneurs en phosphore $(\mathrm{P})$ et en azote $(\mathrm{N})$ dans le sol. Généralement, le travail conventionnel du sol (labour) entraine une diminution 
de l'abondance et de la diversité des organismes du sol, principalement les vers de terre et les micro-organismes, ainsi qu'une distribution homogène des éléments nutritifs ( $\mathrm{P}$ et $\mathrm{N}$ ) dans l'horizon labouré. L'incorporation des résidus de récolte dans le sol peut avoir un effet protecteur pour la matière organique et le retournement du sol permet l'aération du sol, l'activation de l'activité biologique et accroît la disponibilité des nutriments. Néanmoins, l'effet du travail du sol sur l'activité biologique du sol et sur les cycles des éléments nutritifs n'a pas été complétement étudié. Conclusions. L'analyse bibliographique met en évidence la difficulté d'établir des relations pouvant exister entre la gestion des résidus de récolte, l'activité biologique du sol et la disponibilité des éléments nutritifs, notamment en raison de la variabilité agro-pédo-climatique régionale. D'autres recherches doivent être menées sur des sols limoneux en climat tempéré.

Mots-clés. Résidu de récolte, travail du sol, ver de terre, micro-organisme, phosphore, azote, climat tempéré.

\section{INTRODUCTION}

Soil organic matter (SOM) serves a key role in soil fertility under agricultural practices. It is an important source of crop nutrients, as well as a nutrient source for high soil biodiversity levels. Soil macro- and microorganisms are involved in key biological processes, such as carbon dynamics and nutrient cycling (Wardle, 1995). More specifically, earthworms and microorganisms play a range of beneficial roles, including organic matter (OM) mineralization, soil aggregate generation and stabilization, and nutrient stimulation (Lemtiri et al., 2014). However, environmental factors such as climate, as well as anthropogenic activities, particularly agricultural management practices, influence soil biological communities and their functions at different levels. In most soils, more than $90 \%$ of the total nitrogen $(\mathrm{N})$ and sulphur $(\mathrm{S})$, together with $>50 \%$ of the total phosphorus $(\mathrm{P})$ are associated with microbial biomass and $\mathrm{OM}$; therefore cycling and bioavailability of these key soil nutrients are primarily controlled by OM transformation associated with microbial and faunal activity (Bünemann et al., 2007; McNeill et al., 2007). Anthropogenic impacts have dramatically altered global nutrient cycles; in some regions, ecosystems suffer nutrient excesses due to uncontrolled run-off of anthropogenically derived N and P (Vitousek, 2004), whilst in other areas crop production is limited by a lack of these soil elements.

Agriculture also faces a growing demand for the production of bio-products on cultivated lands. Questions regarding best crop residue use, i.e., off-site valorization, simply left on the topsoil (no-till and reduced tillage systems) or mixed within the soil profile using ploughing (conventional tillage), and questions about soil resilience to changes in input/output balance are continually arising and answers should integrate entire soil functioning components. Therefore, we focused this review on the impacts of tillage practices, including conventional and minimum or zero tillage, and crop residue management on biological functioning, and $\mathrm{P}$ and $\mathrm{N}$ cycling. An additional paper (Hiel et al., 2016, same issue) examines the hydrological cycle and crop performance.

\section{LITERATURE}

\subsection{Effects of tillage systems and crop residue incorporation on microbial and earthworm communities}

In the following section, we focus on the effects of tillage and crop residue incorporation on soil microorganisms, the most abundant and diverse group of soil organisms (Roesch et al., 2007) and earthworms, the soil macrofauna integrally involved in soil aggregation processes. Both organisms are well studied and support essential soil ecosystem functions, such as nutrient and soil carbon cycling, disease suppression, organic matter degradation, and soil structure (Wardle, 1995). Holland (2004) reviewed the consequences of conservation agriculture, including crop residue incorporation and the application of minimum or zero tillage on global soil biology. Earthworms are known as ecosystem engineers due to the species' profound impacts on soil habitat: earthworms change soil chemical, physical, and structural properties, which subsequently impact soil biota and ecosystem functioning (Lemtiri et al., 2015). Earthworms and microorganisms are both functional groups, which interact. Earthworms are highly involved in the biochemical decomposition of OM, where they indirectly stimulate microbial activity through fragmentation and ingestion of fresh $\mathrm{OM}$, resulting in an increased surface area available for microbial colonization, which in turn produce enzymes causing OM decomposition (Curry et al., 2007). Therefore, the notable relationship between microorganisms and earthworms is of agronomical interest and is essential to understand in order to assess the impacts of tillage and crop residue incorporation on earthworm biomass, activity, and composition.

Earthworms. Land management practices have considerable impact on earthworm size and dynamics. Agriculture intensification has included various chemical and mechanical applications, often with little consideration of the effects on biologically mediated processes. Organic and inorganic fertilizer sources influence soil fertility, but OM is particularly important as it provides the soil more resilience by smoothing 
inter-annual variation in nutrient availability for soil biota and crop productivity (Palm et al., 1997).

Agricultural practices, such as tillage, alter soil microhabitats and interrupt life cycles. Therefore, it is expected that soil organisms with long life spans, such as earthworms (which live up to six years under optimum conditions) are particularly sensitive (Eriksen-Hamel et al., 2009). Van Capelle et al. (2012) reported a decline in earthworm species diversity due to frequent tillage, which affected soil physical properties with detrimental effects to many soil organisms. For example, tillage affects earthworm populations, which build their galleries and burrows in deeper soil layers. Johnson-Maynard et al. (2007) found intensive and frequent tillage markedly reduced earthworm populations, whilst conservation tillage systems (no-till) promoted an increase in populations. Tillage not only affected earthworm abundance and biomass, but also induced changes in ecological groups and species diversity. Simonsen et al. (2010) showed reduced tillage and manure use positively affected anecic earthworms, whereas conventional tillage practices appeared to benefit endogeic species. Higher earthworm numbers and biomass in conservation tillage agrosystems were attributed to surface litter, SOM accumulation, favorable pedoclimatic conditions, and a reduction in disturbance regimes (Nuutinen, 1992; Wyss et al., 1992). However, in some cases, Kladivko et al. (2001) indicated earthworm abundance and biomass might be equal or slightly lower in no-till compared with conventional tillage agrosystems. One factor responsible for this inconsistency is that tillage often occurs in conjunction with the incorporation of crop residues, which are food sources for earthworms.

Tillage systems more rapidly affect some earthworm ecological groups relative to others. Clear ploughing effects were demonstrated for anecic and epigeic species, as these two groups require soil surface litter and cannot tolerate regular habitat disturbance. Studies showed endogeic earthworms exhibited reduced sensitivity to soil inversion and were less impacted by tillage systems; endogeic earthworms were even sometimes favored by ploughing, as access to OM was facilitated when crop residues were buried and partially decomposed by soil microorganisms (Nuutinen, 1992; Wyss et al., 1992). The endogeic earthworm Aporectodea caliginosa is generally considered to be tolerant of soil tillage (Peigné et al., 2009; Rosas-Medina et al., 2010), although de Oliveira et al. (2012) found it to be more sensitive to tillage than Aporectodea rosea. Berner et al. (2008) reported ploughing decreased endogeic species abundance. Ploughing and various conservation tillage systems were compared and results showed that the number of adult endogeic earthworms was $70 \%$ higher for conservation tillage, whilst total biomass was $50 \%$ lower and individual biomass under conservation tillage was only one-third of that in soil under ploughing (Berner et al., 2008). The authors argued that food resources were more favorable for endogeic worms in ploughed plots than in plots subjected to conservation tillage. However, Chan (2001) examined the impacts of conventional tillage practices on earthworm population density and reported conflicting results. Therefore, depending on the quality and quantity of residues incorporated in the soil versus that left on the surface, tillage may inhibit or enhance earthworm populations (Chan, 2001; Zaller et al., 2004). Cropping systems where cereals are under-sown with legumes support higher earthworm numbers and biomass than those with monoculture cereals (Schmidt et al., 2003). This could be due to tillage reduction, higher organic matter input, or higher quality residue composition following a cereal-legume intercrop, which might be more favorable to earthworms. The importance of these factors was investigated in a field experiment at Long Ashton Research Station, UK, where earthworm populations under conventional wheat, direct-drilled wheat, and direct-drilled wheat-clover intercrops were compared (Schmidt et al., 2003). The results indicated the following:

- the absence of ploughing alone had only a modest effect on earthworm populations;

- the combination of ploughing and the presence of a clover understory substantially increased earthworm populations.

Schmidt et al. (2003) concluded that earthworm populations exhibited decreased benefits from reduced soil disturbance relative to the enhanced quantity, nutritional quality, and continuity of food supply in wheat-clover intercrops.

Earthworm growth and reproduction are often limited by food availability in agricultural soils. Therefore, cropping regimes influence earthworm structure and population density (Shuster et al., 2003). In conventional tillage systems, crop residues are incorporated into the soil, which might increase residue availability for earthworms feeding at the soil surface. Fortune et al. (2005) established a field experiment to investigate the effects on earthworms of non-inversion tillage versus conventional tillage, and straw chopping versus baling and removing. After four years, earthworm abundance and biomass increased in conservation tillage, where straw was incorporated. However, earthworm population response to crop residues depended primarily on the residue's biochemical characteristics. Earthworm populations were larger in long-term conservation compared with conventional tillage plots; however, crop residue management did not affect earthworm populations, possibly due to the high $\mathrm{C}: \mathrm{N}$ ratio of straw. 
Microorganisms. Soil microbial communities, including bacteria and fungi, are other important actors in maintaining soil ecosystem functioning and sustainability (Singh et al., 2011; Paul, 2014). Organic matter is the main nutrient source for soil organisms, thus adding or not adding organic products (animalor plant-based) to soil is expected to have an effect on the microbial properties. Kallenbach et al. (2011) conducted a meta-analysis of 41 studies to assess microbial biomass responses to diverse types of organic amendments (solid, raw, or composted animal derived materials, and plant derived residues) relative to systems that received only inorganic fertilizer applications. The meta-analysis included a broad range of soil types, cropping systems, and geographic locations. Results showed that climate and edaphic soil properties, as well as crop and soil management practices, imposed a diverse range of constraints on soil microbial biomass responses to organic amendments, but, in all studies, adding organic amendments led to significant increases in microbial biomass.

In addition to global positive effects of organic amendments on microbial biomass, interest in how crop residue's location in the soil profile impacts on microbial properties is also represented in the literature. Franzluebbers (2002) indicated that conventional tillage restricted the organic amendment to the plough layer, whilst conservation tillage systems, such as zero- or reduced-tillage applied the crop residues at or close to the soil surface which generated a decreasing gradient of residue content from surface to depth.

Given the vertical gradient observed in conservation tillage and the close dependence of microbial communities on resource quality and availability, differences in microbial properties between conservation and conventional tillage systems can be expected. For example, Fierer et al. (2003) reported soil microbial biomass decreased with depth and tillage practice effects on microbial biomass were more pronounced at the soil surface compared with deeper horizons. Globally, conservation tillage systems, such as zero-tillage, increased microbial biomass relative to conventional tillage practices in long-term field experiments (Helgason et al., 2009; Helgason et al., 2010; van Groenigen et al., 2010; Wang et al., 2012; Shi et al., 2013).

Furthermore, in addition to biomass, the relationship between functional microbial group structures, including bacteria, fungi and arbuscular mycorrhizal fungi (AMF) and crop residue localization have been investigated by several methods, such as phospholipid fatty acid profiles (PLFA). For example, Wang et al. (2012) showed that the tillage system impacts on microbial structure; conservation tillage increased AMF while conventional tillage increased bacteria. Results indicated that conventional tillage significantly decreased soil fungi by physically disrupting fungal hyphal networks. However, Helgason et al. (2010) reported that crop residue placement did not influence microbial community structure.

Höflich etal.(1999) conducted a survey toinvestigate conservation versus conventional tillage impacts in two soil types (sandy loam and loamy sand). The study examined the effects on specific microbial group distribution and activity in the rhizosphere (Rhizobium spp., mycorrhizal species, Pseudomonas spp.; each of which play integral roles in successful agriculture). Results suggested that conservation tillage stimulated rhizosphere bacteria, particularly Agrobacterium spp. and Pseudomonas spp. Nodulation and $\mathrm{N}_{2}$ fixation from Rhizobium spp. also increased, but only in sandy loam. Finally, no differences in rhizosphere colonization by mycorrhizal and saprophytic fungi between both tillage practices were observed.

More recently, the discipline has benefited from rapid developments in massive parallel DNA sequencing technologies (New Generation Sequencing - NGS), which provide quick and deep sequencing of metagenomic DNA at moderate costs, allowing detailed assessments of soil microbial communities with higher phylogenetic resolution, which provide more taxonomic information than previous classical sequencing techniques (e.g., Sanger) which required considerably more time and money (Cardenas et al., 2008). There have now been a number of surveys to investigate the influence of crop residue utilization combined with different tillage systems using massive parallel DNA sequencing (Ceja-Navarro et al., 2010; Navarro-Noya et al., 2013; Degrune et al., 2015). Degrune et al. (2015) reported significant effects of tillage practices on bacterial and fungal community composition, while influences of crop residue utilization were not observed. NavarroNoya et al. (2013), however, found that crop residue utilization and tillage practice impacted on different bacterial groups. Ceja-Navarro et al. (2010) showed some functional bacterial groups, such as fluorescent Pseudomonas spp. and Burkholderiales were favored by residue incorporation and negatively affected by residue removal. As compared to the experiment of Degrune et al. (2015), located in a temperate climate region, others have been conducted under semi-arid conditions. This could explain the differences observed concerning the influence of crop residue management and tillage.

To conclude, the large majority of authors reported that leaving crop residues at the soil surface, combined with zero or minimum soil disturbance was beneficial for soil earthworm and microbe activities, organisms integrally involved in ecosystem functioning, and therefore enhancing soil quality. However, variability in parameters was observed in the studies, including 
soil type, climate, season, crop, sampling depth, and experiment duration. The influence of crop residue management on microbial communities under various tillage regimes should consider all variables to fully elucidate soil microbial community dynamics.

\subsection{Nutrient availability: phosphorus and nitrogen}

Phosphorus $(\mathrm{P})$ and nitrogen $(\mathrm{N})$ are major crop nutrients, which must be added to soils when levels are insufficient to ensure acceptable crop production (i.e., yield). Indeed, if $\mathrm{OM}$ mineralization by microorganisms is a key process in making $\mathrm{P}$ and $\mathrm{N}$ available for plant nutrition, mineral fertilizers can be applied as directly available nutrient sources. However, unmanaged chemical fertilizer use often generates environmental and economic concerns. For example, chemical fertilizer production is derived from nonrenewable resources, including fossil fuels (Cordell et al., 2009). In addition, $\mathrm{P}$ and $\mathrm{N}$ application can result in eutrophication of surface water, including but not limited to lakes, rivers, and estuaries, or leaching towards groundwater and subsequent contamination (Carpenter et al., 1998). Therefore, appropriate $\mathrm{N}$ and $\mathrm{P}$ management is critical to ensure agricultural sustainability with minimal negative environmental impacts.

Clearly, benefits and concerns surround the potential to apply $\mathrm{P}$ and $\mathrm{N}$ as a nutrient source in plants, resulting in interest in optimizing application management. Crop residues show potential for the following valorization schemes: animal feeding, energy production, construction materials, bio-sourced molecules, and of course soil fertility conservation. Presently, studies have not shown the compatibility level between crop residue exportation and sustainable soil health.

Phosphorus. Phosphorus is a limiting nutrient for biological productivity in numerous ecosystems. Most agrosystems rely on mineral P-fertilizers and organic manure applications, even under widely variable conditions worldwide, but including temperate regions, where we focus our review. Organic $\left(\mathrm{P}_{\text {orga }}\right)$ and inorganic $\left(\mathrm{P}_{\text {inorga }}\right)$ phosphorus comprise a respective $30-65 \%$ and $35-70 \%$ of total phosphorus $\left(\mathrm{P}_{\text {tot }}\right)$ in soils (Harrison, 1987). This chapter specifically examines the question of soil crop residue management impacts from restitution versus exportation, and soil tillage.

The following points should be emphasized regarding $\mathrm{P}$ :

$-96 \%$ of the $\mathrm{P}$ taken up by plants is derived from dissolved forms $\left(\mathrm{H}_{2} \mathrm{PO}_{4}^{-}, \mathrm{HPO}_{4}^{2-}, \mathrm{PO}_{4}^{3-}\right)$ (Beck et al., 1994);

- inorganic phosphorus is weakly available to plants due to low mineral solubility and strong interactions (sorption, precipitation) with soil constituents (e.g., only $9 \%$ of $\mathrm{P}_{\text {tot }}$ in Belgian soils; Renneson et al. [2013]);

- phosphate rocks of high quality are expected to disappear in the upcoming decades (Cordell et al., 2009);

- mobilization of organic P sources in soils strongly relies on factors governing OM mineralization.

Crop residues contain inorganic and organic $\mathrm{P}$ forms, easily available for plants and microorganisms (Noack et al., 2012). Orthophosphates $\left(\mathrm{PO}_{4}^{3-}\right)$ are dominant in crop residues, which can be directly taken up by plants, immobilized by microorganisms, or sorbed to soil minerals. Noack et al. (2012) reported that $\mathrm{P}_{\text {orga }}$ from residues can be mineralized to $\mathrm{P}_{\text {inorga }}$ and subsequently stabilized, reducing $\mathrm{P}_{\text {orga }}$ availability. Nevertheless, crop residue incorporation effects on soil $\mathrm{P}$ mobility remain unclear and results of studies show a lack of congruency. Ohno et al. (1997) observed the release of dissolved organic carbon from crop residues in acidic soils, inhibiting $\mathrm{P}$ adsorption rates into soils. This was due to aluminium ( $\mathrm{Al}$ ) surface complexation by dissolved OM ligands, and desorption of the complex into soil solution, resulting in increased soil $\mathrm{P}$ availability. However, Varinderpal-Singh et al. (2006) reported crop residue incorporation in neutral soils increased maximum $\mathrm{P}$ adsorption, as well as resistance to $\mathrm{P}$ release in soil solution, resulting in decreased $\mathrm{P}$ desorption. Wang et al. (2011) found increased $\mathrm{P}_{\text {to }}$ content with residue incorporation, decreased $\mathrm{P}_{\text {orga }}$, and no change in available $\mathrm{P}\left(\mathrm{P}_{\mathrm{av}}\right)$. The study concluded that residues had no effect on $\mathrm{P}$ content under conventional tillage. Soil reaction constituted an important factor, as different $\mathrm{P}$ immobilization effects correlated with soil $\mathrm{pH}$. However, processes were also dependent on residue characteristics (type, quantity, and $\mathrm{C}$ : $\mathrm{P}$ ratio, among others), soil $\mathrm{P}$ richness, and environmental factors (e.g., climatic conditions, soil properties).

Tillage practices can also influence $\mathrm{P}$ release from crop residue. Coppens et al. (2006) showed mixing crop residues with soil particles by mouldboard plough practices resulted in accelerated residue decomposition and subsequently increased nutrient release. Wang et al. (2011) showed $\mathrm{P}_{\text {tot }}$ and $\mathrm{P}_{\text {orga }}$ contents were higher under conservation compared with conventional tillage treatments, whereas significant differences in $\mathrm{P}_{\text {av }}$ were not observed.

Deubel et al. (2011) investigated the influence of tillage treatments on element spatial distribution, which included $\mathrm{P}$ within the soil profile. Evidence indicated that crop residues under conventional tillage were distributed uniformly throughout the plough layer. However, under a conservation tillage system, residues were not incorporated in the plough layer and decomposed at the soil surface, resulting in OM accumulation, which released $\mathrm{P}$ in the soil surface layer. 
This accumulation was heightened by $\mathrm{P}$ amendments via inorganic fertilizer or animal manure applications (Sharpley, 2003).

Nevertheless, tillage treatments exhibited minimal effects on $\mathrm{P}_{\text {tot }}$ content. Piegholdt et al. (2013) reported a slight increase in soil $\mathrm{P}$ content under a conservation tillage system compared with conventional tillage in German Luvisols. However, Sharpley (2003) indicated that ploughing increased soil $\mathrm{P}$ retention under conservation tillage practices. In addition, maximum $\mathrm{P}$ sorption and minimum $\mathrm{P}$ sorption saturation were observed by mixing topsoil $(0-5 \mathrm{~cm})$ and subsoil $(5-20 \mathrm{~cm})$ (Sharpley, 2003).

Nitrogen. Nitrogen is one of the most deficient nutrients in agricultural soils and hence the major fertilizer used in agriculture. Nitrogen can be found in organic and inorganic forms. Organic $\mathrm{N}$ availability is slow compared to inorganic, but the risks of $\mathrm{N}$ escape from soils to other environmental components are also reduced. The primary $\mathrm{N}$ forms available for plant nutrition are nitric $\left(\mathrm{NO}_{3}-\mathrm{N}\right)$ and ammonium $\left(\mathrm{NH}_{4}-\mathrm{N}\right)$. Crop residues are the main organic source of soil nutrients, and residue return was shown to enhance soil nitrogen stocks (Dolan et al., 2006; Malhi et al., 2006; Malhi et al., 2010).

Chen et al. (2014) found the following four pathways were responsible for soil inorganic nitrogen conditioning:

- biotic immobilization/demineralization by microbes; - abiotic immobilization into dissolved organic or recalcitrant $\mathrm{N}$;

- soil organic matter mineralization;

- organic plant residue mineralization.

Returning crop residues to soil should have direct effects on the fluxes from pathway, but should also improve the immobilization rates into microbial biomass, demineralization rate from microbes, and microbe mortality.

Chen et al. (2014) found that residue decay rates were generally slower at the surface under conservation practices than when incorporated in the soil under conventional tillage, where $\mathrm{N}$ release was delayed from residues under conservation tillage systems. However, crop residue placement effects within the soil profile using tillage practice on $\mathrm{N}$ content remain unclear. Dolan et al. (2006) conducted a survey under continental climate conditions (Minnesota, USA) and found the absence of tillage effects for the entire soil profile $(0-45 \mathrm{~cm})$, however effects were observed for specific soil profile layers. At the soil surface $(0-15 \mathrm{~cm}), \mathrm{N}$ content was higher under conservation tillage; the $15-20 \mathrm{~cm}$ depth was considered a transition zone; and at $20 \mathrm{~cm}$ and below, $\mathrm{N}$ content was higher under ploughed soil. Angers et al. (1997) in eastern
Canada reached the same conclusions. However, Brennan et al. (2014) conducted a survey under a cool Atlantic climate in Ireland between 2009 and 2011 and concluded that $\mathrm{N}$ response was similar for conventional and conservation tillage, and crop residue utilization (returned to soil or removed) had very little effect on plant $\mathrm{N}$ uptake.

Malhi et al. (2010) conducted a field experiment in Alberta, Canada and demonstrated that a combination of returning crop residues and conservation tillage increased the total and light fraction $\mathrm{N}$ content in the 0-15 cm soil layer compared with conventional tillage. However, differences were not observed for $\mathrm{NO}_{3}-\mathrm{N}$ content. Thus, $\mathrm{N}$ response to crop residue management might change with the $\mathrm{N}$ form under consideration. Chen et al. (2014) suggested ploughing time is also a factor to include.

Furthermore, in addition to crop residue utilization, it is important to examine crop residue composition. A low $\mathrm{C}: \mathrm{N}$ ratio (e.g., residues from legume crops) will generally induce residue mineralization by microbes, whereas a high $\mathrm{C}: \mathrm{N}$ ratio will cause immobilization by microbes; consequently $\mathrm{N}$ is no longer available for plant nutrition (Christopher et al., 2007). Morris et al. (2010) and Chen et al. (2014) report that returning cereal straw to soils without tillage can promote a negative effect on the next generation of crops due to immobilization of mineral $\mathrm{N}$ by microbes. However, crops that are able to fix nitrogen from the atmosphere due to the presence of a specific group of microorganisms (Rhizobium sp.) or crops with long growth periods are less sensitive to this phenomenon (Chen et al., 2014).

\section{CONCLUSIONS}

The fate of crop residues (exportation, incorporation, one or the other system) is crucial in earthworm and microbial communities viability, and $\mathrm{P}$ and $\mathrm{N}$ availability are essential soil fertility elements.

Soil macro- and microorganisms, including earthworms and microbial communities, are potentially key indicators of soil health. These organisms respond rapidly to changes in soil conditions, such as crop residue management and tillage systems. Overall, under most conditions, incorporating crop residues, which is the main nutrient source for soil biota, into the soil had favorable effects on earthworm and microbial communities. However, burying crop residues using ploughing systems exhibited harmful effects on soil earthworms and microorganisms, such as fungi communities. Ploughing induced increased disturbance to larger organisms, such as earthworms and fungi, although bacteria located in soil micropores were less affected. 
Field experiments also showed divergent effects of crop residue incorporation and tillage systems on soil phosphorus levels and forms. However, the evolution of soil nutrient content was clearly dependent on a balance of inputs and outputs. Tillage influenced $\mathrm{P}$ content and spatial distribution within the soil profile. Ploughing generated $\mathrm{P}$ accumulation in the soil surface layer. Crop residues that remained on fields and decomposed at the soil surface heightened $\mathrm{P}$ accumulation. Therefore, reduced tillage and residue conservation might improve $\mathrm{P}$ availability. However, based on the lack of congruence from various studies regarding crop residue and tillage treatment effects on soil $\mathrm{P}$ dynamics, further studies are required.

A clear positive effect of leaving residues, when combined with reduced tillage, is increased soil nitrogen stock. In all cases, leaving crop residues on fields increased soil $\mathrm{N}$ content, while the effects of tillage changed according to residue localization depth. It is vital to consider residue composition, as a high $\mathrm{C}: \mathrm{N}$ ratio generally causes microbial immobilization while a low $\mathrm{C}: \mathrm{N}$ ratio favors mineralization and $\mathrm{N}$ availability for crops.

Research provides evidence that crop residue management and tillage systems influence soil biological activity and nutrient cycling, which differ according to experiment location and duration. In this review, we examined experiments conducted under temperate climates, however we did not consider factors such as soil type, which can influence biotic activity, and therefore the processes that change nutrient availability.

\section{Bibliography}

Angers D.A. et al., 1997. Impact of tillage practices on organic carbon and nitrogen storage in cool, humid soils of eastern Canada. Soil Tillage Res., 41(3-4), 191-201.

Beck M.A. \& Sanchez P.A., 1994. Soil phosphorus fraction dynamics during 18 years of cultivation on a typic paleudult. Soil Sci. Soc. Am. J., 58(5), 1424-1431.

Berner A. et al., 2008. Crop yield and soil fertility response to reduced tillage under organic management. Soil Tillage Res., 101(1-2), 89-96.

Brennan J. et al., 2014. The effect of tillage system and residue management on grain yield and nitrogen use efficiency in winter wheat in a cool Atlantic climate. Eur. J. Agron., 54, 61-69.

Bünemann E.K. \& Condron L.M., 2007. Phosphorus and sulphur cycling in terrestrial ecosystems. In: Marschner D.P. \& Rengel P.D.Z., eds. Nutrient cycling in terrestrial ecosystems. Soil biology. Berlin, Deutschland: Springer, 65-92.

Cardenas E. \& Tiedje J.M., 2008. New tools for discovering and characterizing microbial diversity. Curr. Opin. Biotechnol., 19(6), 544-549.
Carpenter S.R. et al., 1998. Nonpoint pollution of surface waters with phosphorus and nitrogen. Ecol. Appl., 8(3), 559-568.

Ceja-Navarro J.A. et al., 2010. Phylogenetic and multivariate analyses to determine the effects of different tillage and residue management practices on soil bacterial communities. Appl. Environ. Microbiol., 76(11), 3685-3691.

Chan K.Y., 2001. An overview of some tillage impacts on earthworm population abundance and diversity implications for functioning in soils. Soil Tillage Res., 57(4), 179-191.

Chen B. et al., 2014. Soil nitrogen dynamics and crop residues. A review. Agron. Sustainable Dev., 34(2), 429-442.

Christopher S.F. \& Lal R., 2007. Nitrogen management affects carbon sequestration in North American cropland soils. Crit. Rev. Plant Sci., 26(1), 45-64.

Coppens F. et al., 2006. Soil moisture, carbon and nitrogen dynamics following incorporation and surface application of labelled crop residues in soil columns. Eur. J. Soil Sci., 57(6), 894-905.

Cordell D., Drangert J.-O. \& White S., 2009. The story of phosphorus: global food security and food for thought. Global Environ. Change, 19(2), 292-305.

Curry J.P. \& Schmidt O., 2007. The feeding ecology of earthworms-a review. Pedobiologia, 50(6), 463-477.

De Oliveira T., Bertrand M. \& Roger-Estrade J., 2012. Short-term effects of ploughing on the abundance and dynamics of two endogeic earthworm species in organic cropping systems in northern France. Soil Tillage Res., 119, 76-84.

Degrune F. et al., 2015. A novel sub-phylum method discriminates better the impact of crop management on soil microbial community. Agron. Sustainable Dev., 35, 1157-1166.

Deubel A., Hofmann B. \& Orzessek D., 2011. Long-term effects of tillage on stratification and plant availability of phosphate and potassium in a loess chernozem. Soil Tillage Res., 117, 85-92.

Dolan M.S. et al., 2006. Soil organic carbon and nitrogen in a Minnesota soil as related to tillage, residue and nitrogen management. Soil Tillage Res., 89(2), 221-231.

Eriksen-Hamel N.S. et al., 2009. Earthworm populations and growth rates related to long-term crop residue and tillage management. Soil Tillage Res., 104(2), 311-316.

Fierer N., Shimel J.P. \& Holden P.A., 2003. Variations in microbial community composition through two soil depth profiles. Soil Biol. Biochem., 35, 167-176.

Fortune T. et al., 2005. Reduced cultivations - Update from Oak park experiments. In: Proceedings of the National tillage conference 2005, Teagasc, Carlow, Ireland, 1834.

Franzluebbers A.J., 2002. Soil organic matter stratification ratio as an indicator of soil quality. Soil Tillage Res., 66(2), 95-106. 
Harrison A.F., 1987. Soil organic phosphorus : a review of world literature. Wallingford, UK: CABI.

Helgason B.L., Walley F.L. \& Germida J.J., 2009. Fungal and bacterial abundance in long-term no-till and intensive-till soils of the Northern Great Plains. Soil Sci. Soc. Am. J., 73(1), 120-127.

Helgason B.L., Walley F.L. \& Germida J.J., 2010. Longterm no-till management affects microbial biomass but not community composition in Canadian prairie agroecosytems. Soil Biol. Biochem., 42(12), 2192-2202.

Hiel et al., 2016. Crop residue management in arable cropping systems under a temperate climate. Part 2: Soil physical properties and crop production. A review. Biotechnol. Agron. Soc. Environ., 20(S1), 245-256.

Höflich G. et al., 1999. Influence of long-term conservation tillage on soil and rhizosphere microorganisms. Biol. Fertil. Soils, 29(1), 81-86.

Holland J.M., 2004. The environmental consequences of adopting conservation tillage in Europe: reviewing the evidence. Agric. Ecosyst. Environ., 103(1), 1-25.

Johnson-Maynard J.L., Umiker K.J. \& Guy S.O., 2007. Earthworm dynamics and soil physical properties in the first three years of no-till management. Soil Tillage Res., 94(2), 338-345.

Kallenbach C. \& Grandy A.S., 2011. Controls over soil microbial biomass responses to carbon amendments in agricultural systems: a meta-analysis. Agric. Ecosyst. Environ., 144(1), 241-252.

Kladivko E.J., 2001. Tillage systems and soil ecology. Soil Tillage Res., 61(1-2), 61-76.

Lemtiri A. et al., 2014. Impacts of earthworms on soil components and dynamics. A review. Biotechnol. Agron. Soc. Environ., 18(1), 121-133.

Lemtiri A. et al., 2015. Earthworms Eisenia fetida affect the uptake of heavy metals by plants Vicia faba and Zea mays in metal-contaminated soils. Appl. Soil Ecol. (in press), http://dx.doi.org/10.1016/j.apsoil.2015.11.021

Malhi S.S. et al., 2006. Tillage, nitrogen and crop residue effects on crop yield, nutrient uptake, soil quality, and greenhouse gas emissions. Soil Tillage Res., 90(1-2), 171-183.

Malhi S.S. et al., 2010. Long-term tillage, straw and $\mathrm{N}$ rate effects on quantity and quality of organic $\mathrm{C}$ and $\mathrm{N}$ in a Gray Luvisol soil. Nutr. Cycling Agroecosyst., 90(1), 1-20.

McNeill A. \& Unkovich M., 2007. The nitrogen cycle in terrestrial ecosystems. In: Marschner D.P. \& Rengel P.D.Z., eds. Nutrient cycling in terrestrial ecosystems. Soil biology. Berlin; Heidelberg, Deutschland: Springer, 37-64.

Morris N.L. et al., 2010. The adoption of non-inversion tillage systems in the United Kingdom and the agronomic impact on soil, crops and the environment. A review. Soil Tillage Res., 108(1-2), 1-15.

Navarro-Noya Y.E. et al., 2013. Relative impacts of tillage, residue management and crop-rotation on soil bacterial communities in a semi-arid agroecosystem. Soil Biol. Biochem., 65, 86-95.

Noack S.R. et al., 2012. Crop residue phosphorus: speciation and potential bio-availability. Plant Soil, 359(1-2), 375-385.

Nuutinen V., 1992. Earthworm community response to tillage and residue management on different soil types in southern Finland. Soil Tillage Res., 23(3), 221-239.

Ohno T. \& Erich M.S., 1997. Inhibitory effects of crop residue-derived organic ligands on phosphate adsorption kinetics. J. Environ. Qual., 26(3), 889-895.

Palm C.A., Myers R.J. \& Nandwa S.M., 1997. Combined use of organic and inorganic nutrient sources for soil fertility maintenance and replenishment. In: Buresh R.J., Sanchez P.A. \& Calhoun F., eds. Replenishing soil fertility in Africa. Madison, WI, USA: Soil Science Society of America (SSSA), 193-217.

Paul E.A., ed., 2014. Soil microbiology, ecology and biochemistry. London: Academic Press.

Peigné J. et al., 2009. Earthworm populations under different tillage systems in organic farming. Soil Tillage Res., 104(2), 207-214.

Piegholdt C. et al., 2013. Long-term tillage effects on the distribution of phosphorus fractions of loess soils in Germany. J. Plant Nutr. Soil Sci., 176(2), 217-226.

Renneson M. et al., 2013. Relationships between the P status of surface and deep horizons of agricultural soils under various cropping systems and for different soil types: a case study in Belgium. Soil Use Manage., 29(suppl. 1), 94-102.

Roesch L.F.W. et al., 2007. Pyrosequencing enumerates and contrasts soil microbial diversity. ISME J., 1(4), 283-290.

Rosas-Medina M.Á. et al., 2010. Effect of tillage, sampling date and soil depth on earthworm population on maize monoculture with continuous stover restitutions. Soil Tillage Res., 108(1), 37-42.

Schmidt O., Clements R.O. \& Donaldson G., 2003. Why do cereal-legume intercrops support large earthworm populations? Appl. Soil Ecol., 22(2), 181-190.

Sharpley A.N., 2003. Soil mixing to decrease surface stratification of phosphorus in manured soils. J. Environ. Qual., 32(4), 1375-1384.

Shi Y. et al., 2013. Seasonal variation of microbial biomass, activity, and community structure in soil under different tillage and phosphorus management practices. Biol. Fertil. Soils, 49(7), 803-818.

Shuster W.D. et al., 2003. Population dynamics of ambient and altered earthworm communities in rowcrop agroecosystems in the Midwestern U.S.: the $7^{\text {th }}$ international symposium on earthworm ecology, Cardiff, Wales, 2002. Pedobiologia, 47(5-6), 825-829.

Simonsen J. et al., 2010. Endogeic and anecic earthworm abundance in six Midwestern cropping systems. Appl. Soil Ecol., 44(2), 147-155.

Singh J.S., Pandey V.C. \& Singh D.P., 2011. Efficient soil microorganisms: a new dimension for sustainable 
agriculture and environmental development. Agric. Ecosyst. Environ., 140(3-4), 339-353.

van Capelle C., Schrader S. \& Brunotte J., 2012. Tillageinduced changes in the functional diversity of soil biota - A review with a focus on German data. Eur. J. Soil Biol., 50, 165-181.

van Groenigen K.-J. et al., 2010. Abundance, production and stabilization of microbial biomass under conventional and reduced tillage. Soil Biol. Biochem., 42(1), 48-55.

Varinderpal-Singh, Dhillon N.S. \& Brar B.S., 2006. Effect of incorporation of crop residues and organic manures on adsorption/desorption and bio-availability of phosphate. Nutr. Cycling Agroecosyst., 76(1), 95-108.

Vitousek P.M., 2004. Nutrient cycling and limitation: Hawai' $i$ as a model system. Princeton, NJ, USA: Princeton University Press.

Wang J.B. et al., 2011. Surface soil phosphorus and phosphatase activities affected by tillage and crop residue input amounts. Plant Soil Environ., 57(6), 251-257.
Wang J.J. et al., 2012. Effects of tillage and residue management on soil microbial communities in north China. Plant Soil Environ., 58(1), 28-33.

Wardle D.A., 1995. Impacts of disturbance on detritus food webs in agro-ecosystems of contrasting tillage and weed management practices. Adv. Ecol. Res., 26, 105-185.

Wyss E. \& Glasstetter M., 1992. Tillage treatments and earthworm distribution in a Swiss experimental corn field. Soil Biol. Biochem., 24(12), 1635-1639.

Zaller J.G. \& Köpke U., 2004. Effects of traditional and biodynamic farmyard manure amendment on yields, soil chemical, biochemical and biological properties in a long-term field experiment. Biol. Fertil. Soils, 40(4), 222-229.

(64 ref.) 